\title{
EFEK MODEL PEMBELAJARAN INQUIRY TRAINING BERBASIS MULTIMEDIA DAN MOTIVASI TERHADAP HASIL BELAJAR FISIKA SISWA
}

\author{
Hayati dan Retno Dwi Suyanti \\ Program Magister Pendidikan Fisika, Universitas Negeri Medan
}

\begin{abstract}
Abstrak. Penelitian ini bertujuan untuk: (1) Menentukan model pembelajaran yang lebih baik dalam meningkatkan hasil belajar Fisika siswa diantara model pembelajaran Inquiry Training berbasis multimedia dan model pembelajaran Inquiry Training. (2) Mengetahui tingkat motivasi belajar dalam mempengaruhi hasil belajar Fisika siswa. (3) Mengetahui interaksi antara model pembelajaran dengan motivasi dalam mempengaruhi hasil belajar siswa. Penelitian ini merupakan penelitian quasi eksperimen. Populasi penelitian ini adalah seluruh siswa kelas XI SMA Negeri 1 Sunggal Semester I T.P 2012/2013. Sampel penelitian terdiri dari dua kelas dengan jumlah sampel 70 orang yang ditentukan dengan purposive sampling, yaitu XI IPA-2 sebagai kelas eksperimen menggunakan model pembelajaran Inquiry Training berbasis multimedia sebanyak 35 orang dan XI IPA-3 sebagai kelas kontrol menggunakan model pembelajaran Inquiry Training sebanyak 35 orang. Hipotesis dianalisis menggunakan GLM pada taraf signifikan 0,05 dengan bantuan SPSS 17.0 for windows. Berdasarkan analisis data dan uji hipotesis yang dilakukan diperoleh bahwa: (1) Model pembelajaran Inquiry Training berbasis multimedialebih baik dalam meningkatkan hasil belajar fisika siswa daripada model pembelajaran Inquiry Training. (2) Hasil belajar fisika siswa yang memiliki motivasi belajar tinggi lebih baik daripada siswa yang memiliki motivasi belajar rendah. (3) Dari penelitian ini juga terdapat interaksi antara model pembelajaran inquiry training berbasis multimedia dan motivasi belajar siswa terhadap hasil belajar siswa.
\end{abstract}

Kata kunci: model pembelajaran, inquiry training, multimedia, motivasi, hasil belajar

\section{EFFECTS OF INQUIRY TRAINING LEARNING MODEL BASED MULTIMEDIA AND MOTIVATION OF PHYSICS STUDENT LEARNING OUTCOMES}

\author{
Hayati and Retno Dwi Suyanti \\ Graduate Program Physics Education, State University Of Medan
}

\begin{abstract}
The objective in this research: (1) Determine a better learning model to improve learning outcomes physics students among learning model Inquiry Training based multimedia and Inquiry Training learning model. (2) Determine the level of motivation to learn in affects physics student learning outcomes. (3) Knowing the interactions between the model of learning and motivation in influencing student learning outcomes. This research is a quasi experimental. The population in this research was all students in class XI
\end{abstract}


SMA Negeri 1 T.P Sunggal Semester I 2012/2013. The sample of this research was consisted of two classes with a sample of 70 peoples who are determined by purposive sampling, the IPA XI-2 as a class experiment using a model-based multimedia learning Training Inquiry as many as 35 peoples and XI IPA-3 as a control class using learning model Inquiry Training 35 peoples. Hypotheses were analyzed using the GLM at significant level of 0.05 using SPSS 17.0 for Windows. Based on data analysis and hypothesis testing conducted found that: (1) Training Inquiry-based multimedia learning model in improving student learning outcomes rather than learning model physics Inquiry Training. (2) The results of studying physics students who have high motivation to learn better than students who have a low learning motivation. (3) From this research there was an interaction between learning model inquiry-based multimedia training and motivation to study on learning outcomes of students.

Keywords: models of learning, inquiry training, multimedia, motivation, learning outcomes

\section{PENDAHULUAN}

Kecenderungan pendidikan pembelajaran di Indonesia secara umum dalam kurikulum dan model pembelajaran adalah masih dominan pembelajaran konvensional dan kurang variatifnya model pembelajaran yang diterapkan oleh guru sehingga hanya terjadi komunikasi satu arah dan ilmu di transfer secara cepat dari guru kepada siswa secara drill. Hal inilah yang membuat daya serap siswa lemah karena hanya mendengarkan dari guru.

Sehingga diperlukan perubahan paradigma pembelajaran dari yang berpusat pada guru kepada yang berpusat pada siswa. Hal ini dapat membuat siswa lebih proaktif untuk membangun pengetahuannya sendiri melalui pengalaman belajar dan interaksi dengan lingkungan. Dalam kegiatan belajar mengajar terdapat suatu proses yang menjadi inti kegiatan belajar disebut dengan pembelajaran yang menitikberatkan pada keterlibatan siswa dalam mempelajari sesuatu.

Belajar Fisika adalah suatu proses psikologis berupa tindakan seseorang untuk merekonstruksi, memahami suatu gejala alam. Tindakan yang dimaksudkan adalah pengalaman belajar Fisika berupa reaksi orang yang belajar terhadap materi Fisika sebagai bahan ajar. Belajar Fisika pada dasarnya, suatu proses yang diarahkan pada suatu gejala alam yang terjadi. Mata pelajaran Fisika pada sekolah diajarkan untuk membekali peserta didik pengetahuan, pemahaman, konsep dan sejumlah kemampuan untuk memasuki jenjang pendidikan yang lebih tinggi serta mengembangkan ilmu dan teknologi.

Bagi siswa pembelajaran Fisika sering membosankan sehingga pelajaran cenderung diabaikan oleh siswa dalam proses belajarnya karena pelajaran yang berlangsung di sekolah ternyata masih sangat teoritis dan kurang menerapkan model pembelajaran yang sudah banyak dikembangkan oleh para ahli sampai saat ini dan proses belajar cenderung sepihak.

Seringnya sikap guru yang memberikan pembelajaran Fisika dengan konvensional seperti ekspositori, mengajak siswa untuk membaca bahan ajar, menghafal mengakibatkan siswa cenderung merasa bosan, jengkel, dan tidak adanya kemauan dalam benak siswa untuk mendalaminya. Dalam suatu proses belajar mengajar guru berperan sebagai motivator dan fasilitator. Guru harus dapat merangsang dan memberikan dorongan serta reinforcement untuk mendinamiskan potensi siswa, aktivitas, kreativitas sehingga akan 
terjadi dinamika di dalam proses belajar mengajar dan memberikan fasilitas atau memudahkan dalam proses belajar mengajar.

Berdasarkan hasil observasi selama mengajar di SMA Negeri 1 Sunggal, ditemukan bahwa guru masih mengajar secara konvensional yang dominan menerapkan strategi ekspositori, sehingga siswa cenderung pasif, individual, dan kurang berpartisipasi secara aktif dalam proses pembelajaran. Penggunaan media juga masih kurang dilakukan oleh guru dalam pembelajaran sehingga siswa cenderung mempelajari hal-hal yang bersifat abstrak dan menghapal konsep-konsep yang ada dalam Fisika tanpa mengetahui terciptanya konsep serta unsur yang terkandung dalam suatu konsep.

Oleh karena itu dalam proses belajar mengajar Fisika, agar siswa dapat menguasai konsep-konsep Fisika, maka strategi belajar mengajar harus diarahkan pada keaktifan siswa. Proses aktif dari orang yang belajar atau keaktifan siswa akan memberikan hasil yang lebih bermakna bagi tercapainya tujuan dan tingkat hasil belajar tersebut. Selain itu banyaknya konsep Fisika yang bersifat abstrak yang harus diserap siswa dalam waktu relatif terbatas menjadikan ilmu Fisika menjadi salah satu mata pelajaran yang sulit bagi siswa sehingga banyak siswa gagal dalam belajar. Pada umumnya siswa cenderung belajar dengan hafalan daripada secara aktif membangun pemahaman mereka sendiri terhadap konsep Fisika. Hal inilah yang terjadi di sekolah penelitian, kurangnya pengetahuan guru mengenai strategi pembelajaran yang inovatif bagi pelajaran Fisika, kurangnya kegiatan praktikum dan masih belum memahami dengan baik cara pelaksanaan model maupun metode pembelajaran yang inovatif. Hal inilah yang membuat motivasi dan hasil belajar yang dicapai rendah.

Menurut Joyce (2009) model pembelajaran Inquiry Training dirancang untuk membawa siswa secara langsung ke dalam proses ilmiah melalui latihan-latihan yang dapat memadatkan proses ilmiah tersebut ke dalam periode waktu yang singkat. Tujuannya adalah membantu siswa mengembangkan disiplin dan mengembangkan keterampilan intelektual yang diperlukan untuk mengajukan pertanyaan dan menemukan jawabannya.

Melalui model pembelajaran ini siswa diharapkan aktif mengajukan pertanyaan mengapa sesuatu terjadi kemudian mencari dan mengumpulkan serta memproses data secara logis untuk selanjutnya mengembangkan strategi intelektual yang dapat digunakan untuk dapat menemukan jawaban atas pertanyaan tersebut. Model pembelajaran Inquiry Training dimulai dengan menyajikan peristiwa yang mengandung teka-teki kepada siswa. Siswasiswa yang menghadapi situasi tersebut akan termotivasi menemukan jawaban masalahmasalah yang masih menjadi teka-teki tersebut. Guru dapat menggunakan kesempatan ini untuk mengajarkan prosedur pengkajian sesuai dengan langkah-langkah model pembelajaran Inquiry Training. Dalam perkembangan teknologi sudah banyak yang dapat membantu kegiatan belajar mengajar di kelas seperti video tutorial, animasi flash maupun yang lainnya sehingga mampu mempermudah guru dalam menyampaikan informasi. Dengan adanya teknologi maka proses belajar mengajar menjadi inovatif dan tidak membosankan bagi siswa. Peneliti pun merasa tertarik untuk melaksanakan kegiatan belajar mengajar dengan model inquiry training berbasis multimedia untuk membantu siswa dalam meningkatkan hasil belajar.

Multimedia adalah presentasi materi dengan menggunakan kata-kata sekaligus gambar-gambar (Mayer, 2009). Multimedia merupakan pemanfaatan komputer untuk membuat dan menggabungkan teks, grafik, audio, video dan animasi dengan menggabungkan link dan tool yang memungkinkan pemakai melakukan navigasi, berinteraksi, berkreasi dan berkomunikasi.

Hasil penelitian yang sebelumnya antara lain Sinaga (2011) menemukan bahwa hasil belajar siswa yang diajarkan menggunakan pembelajaran POGIL dengan animasi komputer lebih tinggi dari pada menggunakan pembelajaran konvensional pada materi pokok 
Hayati dan Suyanti, R.D.: E fek Model Pembelajaran Inquiry Training Berbasis Multimedia dan Motivasi Terhadap Hasil Belajar Fisika Siswa.
J urnal Pendidikan Fisika

p-ISSN 2252-732X

e-ISSN 2301-7651 stoikiometri. Sedangkan untuk motivasi belajar siswa yang menggunakan pembelajaran POGIL lebih tinggi dari pada pembelajaran konvensional sebesar 82,78. Mudjiono (2009) menunjukkan terdapat pengaruh model pembelajaran inquiry training berbasis portopolio dan penggunaan media komputer terhadap hasil belajar kimia di SMA yang sangat signifikan. Penelitian Fianora (2009) tentang efektivitas media komputer dan metode praktikum terhadap motivasi dan hasil belajar kimia siswa pada pengajaran elektrolisis, menemukan bahwa pengaruh media komputer dan metode praktikum serta gabungan keduanya sangat signifikan yaitu sebesar 82,00 untuk kelas yang menggunakan media komputer; 78,00 untuk kelas yang menggunakan metode praktikum serta untuk kelas gabungan antara media komputer dan metode praktikum sebesar 85,00 dan ditemukan juga efektivitas dari ketiga hal tersebut sebesar $97,57 \%, 95,33 \%$ dan $98,43 \%$. Sitepu (2012) dengan menerapkan Model Pembelajaran Inquiry Training untuk Meningkatkan Hasil Belajar Siswa kelas VII-2 SMPN 1 Tiga Panahan pada Pelajaran Bahasa Inggris memperoleh hasil belajar Postes I dan II menunjukkan 68,2 dan 76,56 serta aktivitas siswa dari hasil pengamatan pada siklus I dan II antara lain menulis/membaca $51 \%$ dan $41 \%$.

Materi di kelas XI yang dianggap sulit yaitu gerak parabola dengan menggunakan vektor karena pada materi ini siswa harus dapat menganalisis gerak suatu benda dengan menentukan analisis vektor-vektor yang bekerja pada benda tersebut. Hal ini dapat dilihat dari hasil ulangan semester beberapa pokok bahasan Fisika kelas XI yang dicantumkan dalam Tabel 1. Hal ini dapat dilihat dari nilai Fisika kelas XI semester 2, 2 tahun terakhir di SMA Negeri 1 Sunggal tercantum dalam Tabel 1. berikut.

Tabel 1. Data Nilai Rata-rata dan Ketuntasan

Pelajaran Fisika Semester Genap Kelas XI SMA Negeri 1 Sunggal

\begin{tabular}{ccc}
\hline Tahun Pelajaran & Nilai rata-rata & KKM \\
\hline $2010 / 2011$ & 70,00 & 70,00 \\
$2011 / 2012$ & 70,15 & 70,00 \\
\hline
\end{tabular}

Sumber: Arsip Tata Usaha SMAN 1 Sunggal
Berdasarkan hasil studi pendahuluan yang diperoleh di SMA N 1 Sunggal melalui angket yang disebarkan kepada 68 siswa diperoleh data, bahwa 20 siswa kurang menggemari Fisika alasannya karena Fisika sulit dan kurang menarik. Selain itu, 38 siswa jarang membaca buku panduan sebelum diajarkan, 5 siswa jarang mengulang pelajaran dan 5 siswa strategi yang digunakan guru masih kurang interaktif. Dapat disimpulkan bahwa hasil belajar yang diperoleh siswa cenderung masih rendah khususnya untuk mata pelajaran Fisika. Rendahnya hasil belajar Fisika yang diperoleh siswa disebabkan adanya beberapa faktor diantaranya kurangnya pemahaman siswa dan perbedaan intelegensi masing-masing siswa, siswa cenderung menghapal konsep-konsep dan prinsip-prinsip yang ada dalam Fisika tanpa mengetahui terciptanya konsep serta unsur yang terkandung dalam suatu konsep. Hal ini diduga sebagai penyebab ketidakmampuan siswa untuk menerapkan konsep-konsep Fisika dalam kehidupan sehari-hari. Konsep-konsep tersebut akan terasa asing dalam kehidupan siswa dan akan mengurangi motivasi belajar Fisika.

Berdasarkan uraian yang telah dikemukakan, perlu dilakukan penelitian "Efek Model Pembelajaran Inquiry Training Berbasis Multimedia terhadap motivasi dan Hasil Belajar Pada Materi Gerak Parabola di SMA Negeri 1 Sunggal T.P 2012/2013". Berdasarkan latar belakang masalah, ada beberapa masalah diidentifikasi sebagai berikut: Proses pembelajaran Fisika sebagian besar hanya menekankan pada aspek menghapal konsep-konsep, prinsipprinsip atau rumus. Hasil belajar siswa pada mata pelajaran Fisika masih rendah. Penggunaan media belajar yang sesuai dengan materi pelajaran masih jarang. Salah satu materi Fisika yang sulit dipahami oleh siswa adalah materi gerak parabola.

Berdasarkan identifikasi dan batasan masalah, dirumuskan masalahnya: Apakah ada perbedaan hasil belajar Fisika siswa dengan model pembelajaran menggunakan inquiry training dan inquiry training berbasis multimedia? Apakah perbedaan tingkat motivasi 
berpengaruh terhadap hasil belajar Fisika siswa yang diajarkan menggunakan pembelajaran inquiry training dengan siswa yang diajarkan menggunakan pembelajaran inquiry training berbasis multimedia? Apakah terdapat interaksi antara model pembelajaran dengan motivasi dalam mempengaruhi hasil belajar siswa pada materi pokok gerak parabola? Tujuan penelitian yang ingin dicapai adalah untuk mengetahui: Perbedaan model pembelajaran inquiry training dan inquiry training berbasis multimedia terhadap hasil belajar Fisika siswa. Perbedaan tingkat motivasi terhadap hasil belajar Fisika siswa yang diajarkan menggunakan model pembelajaran inquiry training berbasis multimedia dengan siswa yang diajarkan menggunakan model pembelajaran inquiry training. Interaksi antara model pembelajaran dengan motivasi dalam mempengaruhi hasil belajar siswa pada materi pokok gerak parabola.

Menurut Gulo (dalam Trianto, 2007) menyatakan strategi inquiry berarti suatu rangkaian belajar yang melibatkan secara maksimal seluruh kemampuan siswa untuk mencari dan menyelidiki secara matematis, kritis, logis, analitis sehingga mereka dapat merumuskan sendiri penemuannya dengan penuh percaya diri. Model pembelajaran Inquiry Training mengembangkan suatu metode penemuan baru yang menuntun siswa merumuskan hipotesis melalui bertanya.

Multimedia adalah kombinasi dari komputer dan video atau multimedia secara umum merupakan kombinasi tiga elemen yaitu, suara, gambar dan teks atau multimedia adalah kombinasi dari paling sedikit dua media input atau output dari data, media ini dapat berupa audio (suara, musik), animasi, video, teks, grafik dan gambar atau multimedia merupakan alat yang menciptakan presentasi yang dinamis dan interaktif yang mengkombinasikan teks, grafik, animasi, audio dan gambar video.

Menurut Sardiman (2011) motivasi belajar dapat dikatakan sebagai keseluruhan daya penggerak dari dalam dan di dalam diri siswa yang menimbulkan kegiatan belajar, yang menjamin kegiatan kelangsungan dari kegiatan belajar dan yang memberikan arah pada kegiatan belajar, sehingga tujuan yang akan dikehendaki oleh subjek belajar itu dapat dicapai. Salah satu tujuan belajar tersebut adalah meningkatnya hasil belajar setelah melalui proses evaluasi. Menurut Sudjana (2010) hasil belajar adalah kemampuankemampuan yang dimiliki siswa setelah menerima pengalaman belajar.

\section{METODE PENELITIAN}

Penelitian ini termasuk dalam quasi eksperimen. Pada kelas eksperimen diberi perlakukan model pembelajaran inquiry training berbasis multimedia. Sedangkan pada kelas kontrol diberi perlakuan dengan menggunakan model pembelajaran inquiry training. Populasi dalam penelitian ini adalah seluruh siswa kelas XI SMAN 1 Sunggal Kabupaten Deli Serdang Tahun Pelajaran 2012/2013. Kelas XI SMA Negeri 1 Sunggal terdiri dari tiga kelas yang berjumlah 105 orang, selanjutnya dengan menggunakan Purposive Sampling, maka diambil 2 (dua) kelas perlakuan, yaitu kelas XI IPA-2 dan XI IPA3. Sampel dikelompokkan dalam dua kelompok, dimana masing-masing kelompok terdiri dari jumlah siswa yang sama (35 orang).

Rancangan penelitian quasi eksperimen ini dengan desain: control group pretest-postes design. Dengan demikian rancangan penelitian ini adalah tercantum pada Tabel 2 berikut:

Tabel 2. Control Group Pretest-Posttest Design

\begin{tabular}{lccc|}
\multicolumn{1}{c}{ Kelas } & Pretes & Perlakuan & Postes \\
\hline Eksperimen & $\mathrm{Y}_{1}$ & $\mathrm{X}_{1}$ & $\mathrm{Y}_{2}$ \\
Kontrol & $\mathrm{Y}_{1}$ & $\mathrm{X}_{2}$ & $\mathrm{Y}_{2}$ \\
\hline
\end{tabular}

Keterangan:

$\mathrm{X}_{1}=$ Pembelajaran dengan menggunakan modelpembelajaran inquiry training berbasis multimedia pada materi pokok gerak parabola dengan menggunakan analisis vektor.

$\mathrm{X}_{2}=$ Pembelajaran dengan menggunakan model inquiry training pada materi pokok gerak parabola dengan menggunakan analisis vektor. 
$\mathrm{Y}_{1}=$ Pretes yang diberikan kepada kelas eksperimen dan kelas kontrol sebelum perlakuan.

$\mathrm{Y}_{2}=$ Postes yang diberikan setelah adanya perlakuan pada kelas eksperimen dan kelas kontrol.

Adapun desain penelitian untuk ANAVA $2 \times 2$ terdapat pada Tabel 3 berikut:

Tabel 3. Desain Penelitian ANAVA 2 Jalur

\begin{tabular}{|c|c|c|c|}
\hline \multirow{2}{*}{$\begin{array}{c}\text { Motivasi } \\
\text { Belajar (B) }\end{array}$} & \multicolumn{2}{|c|}{ Model Pembelajaran (A) } & \multirow{2}{*}{$\begin{array}{l}\text { Rata- } \\
\text { Rata }\end{array}$} \\
\hline & $\begin{array}{c}\text { Inquiry Training } \\
\text { Berbasis Multimedia }(\mathbf{1})\end{array}$ & $\begin{array}{c}\text { Inquiry } \\
\text { training(2) }\end{array}$ & \\
\hline Rendah (1) & $\mu_{11}$ & $\mu_{12}$ & $\mu_{R}$ \\
\hline Tinggi (2) & $\mu_{21}$ & $\mu_{22}$ & $\mu_{T}$ \\
\hline Rata-Rata & $\mu_{K}$ & $\mu_{e}$ & \\
\hline
\end{tabular}

Keterangan :

$\mu_{11}$ :Rerata motivasi belajar rendah dengan Inquiry Training berbasis multimedia.

$\mu_{12}$ :Rerata-rata motivasi belajar rendah dengan Inquiry training.

$\mu_{21}$ :Rerata motivasi belajar tinggi dengan Inquiry Training berbasis multimedia

$\mu_{22}$ :Rerata motivasi belajar tinggi dengan Inquiry Training.

$\mu_{K}$ :Rerata hasil belajar dengan Inquiry Training berbasis multimedia.

$\mu_{e}$ :Rerata hasil belajar dengan Inquiry Training.

$\mu_{R}$ :Rerata hasil belajar dengan motivasi belajar rendah.

$\mu_{T}$ :Rerata hasil belajar dengan motivasi belajar tinggi.

\section{HASIL PENELITIAN DAN PEMBAHASAN a. Deskripsi Data Statistik}

Hasil pengolahan data untuk masingmasing kelas diperoleh nilai maksimum, nilai minimum, nilai rerata dan Standard Deviasi seperti terdapat dalam ringkasan data pretes kelompok sampel pada Tabel 3.

Tabel 3. Data Pretes Kelompok Sampel

\begin{tabular}{lccccc}
\hline Kelas & N & $\begin{array}{c}\text { Nilai } \\
\text { Maks }\end{array}$ & $\begin{array}{c}\text { Nilai } \\
\text { Min }\end{array}$ & Rerata & $\begin{array}{c}\text { Std. } \\
\text { Dev. }\end{array}$ \\
\hline Eksp & 35 & 63,00 & 48,00 & 54,85 & 3,84 \\
Kntrl & 35 & 64,00 & 47,00 & 54,94 & 4,64 \\
\hline
\end{tabular}

Berdasarkan data pada Tabel 3 terlihat bahwa rata-rata skor pretes pada kelas eksperimen dan kelas kontrol masing-masing adalah 54,85 dan 54,94. Sementara itu, standard Deviasi untuk kelas eksperimen adalah 3,84 sedangkan standard Deviasi untuk kelas kontrol adalah 4,64. Berdasarkan data tersebut terlihat bahwa rata-rata skor pretes kelas kontrol sedikit lebih besar dibandingkan dengan rata-rata skor pretes kelas eksperimen. Namun untuk mengetahui secara lebih jelas mengenai kemampuan awal siswa kelas eksperimen sama atau tidak dengan kelas kontrol akan dilaksanakan uji kesamaan dua rata-rata dengan taraf signifikansi 5\%.

\section{Tes Normalitas Data Pretes}

Secara ringkas, data hasil uji normalitas pretes kelas Inquiry Training (IT) dan Inquiry Training berbasis Multimedia (ITM) dapat dilihat dari Tabel 4 di bawah ini.

Tabel 4. Normalitas Pretes Kelas IT Dan ITM

\begin{tabular}{llll}
\hline No & Uji Normalitas & Sig & Keterangan \\
\hline 1. & Kelas IT & 0,09 & Normal \\
\hline 2. & Kelas ITM & 0,18 & Normal \\
\hline
\end{tabular}

\section{Uji Homogenitas Pretes Kelas IT Dan ITM}

Secara ringkas, data hasil uji homogenitas pretes kelas Inquiry Training dan Inquiry Training berbasis Multimedia dapat dilihat pada Tabel 5 di bawah ini.

Tabel 5. Uji Homogenitas Pretes Kelas IT dan ITM

\begin{tabular}{lll}
\hline Hasil Belajar & Sig & Keterangan \\
\hline Pre tes & 0,12 & Homogen \\
\hline
\end{tabular}

\section{Uji Kesamaan Dua Rerata (Uji-t) \\ Kemampuan Awal}

Pengujian hipotesis ini dilakukan dengan teknik ANAVA dua jalur dengan menggunakan software SPSS 17.0 yang dipakai adalah ANOVA Univariate. Deskripsi statistik output dari ANOVA data motivasi dan hasil belajar Fisika siswa dapat dilihat dalam tabel berikut: Levene's Test of Equality of Error Variances ${ }^{\mathrm{a}}$

\begin{tabular}{llll}
\hline \multicolumn{2}{l}{ Dependent } & Variable $:$ gain_Hasil_Belajar \\
\hline $\mathbf{F}$ & df1 & df2 & Sig. \\
\hline 1,99 & 3 & 66 &, 13 \\
\hline
\end{tabular}


Tabel 6. Output Perhitungan ANOVA 2 Jalur

Tests of Between-Subjects Effects

\begin{tabular}{lll}
\hline Dependent Variable : gain_Hasil_Belajar \\
\hline Source & F & Sig. \\
\hline Kelas & 16,45 &, 00 \\
Motivasi & 4,34 &, 04 \\
Kelas * Motivasi & 7,77 &, 01 \\
\hline
\end{tabular}

$F_{\text {tabel }}$ untuk $\mathrm{dk}$ pembilang 1 dan $\mathrm{dk}$ penyebut 66 pada taraf signifikan 0,05 adalah 3,98. Berdasarkan tabel output ANOVA di atas, maka akan diberikan kesimpulan-kesimpulan yang terkait dengan hipotesis penelitian ini. Berdasarkan pada Tabel 6 di atas, maka hipotesis statistik yang diperoleh adalah:

a. Hipotesis yang pertama yang diajukan $\mathrm{H}_{\mathrm{a}}$ diterima, yaitu terdapat perbedaan hasil belajar Fisika antara kelompok subjek yang diberi model pembelajaran Inquiry Training dengan kelompok yang diberi model pembelajaran Inquiry Trainingberbasis Multimedia, karena $\alpha=0,05$ dan $\mathrm{F}_{\text {hitung }}>$ $F_{\text {tabel }}(16,45>3,98)$.

b. Hipotesis yang kedua yang diajukan $\mathrm{H}_{\mathrm{a}}$ diterima, yaitu terdapat perbedaan hasil belajar Fisika siswa yang memiliki motivasi rendah dengan siswa yang memiliki motivasi belajar tinggi, karena $\alpha=0,05$ dan $F_{\text {hitung }}>F_{\text {tabel }}(4,34>3,98)$.

c. Hipotesis yang ketiga yang diajukan $\mathrm{H}_{\mathrm{a}}$ diterima, yaitu terdapat interaksi antara model pembelajaran Inquiry Training dan Inquiry Training berbasis Multimedia dengan motivasi belajar siswa untuk meningkatkan hasil belajar Fisika, karena $\alpha$ $=0,05$ dan $F_{\text {hitung }}<F_{\text {tabel }}(7,77<3,98)$.

\section{Pengujian Persyaratan Analisis}

Sebelum hipotesis diuji perlu dilakukan uji persyaratan analisis data, yaitu data yang berdistribusi normal dan homogen agar hasil penelitian dapat dipertanggungjawabkan.

\section{Uji Normalitas Data}

Uji normalitas data dilakukan dengan bantuan program SPSS.17.0 for windows dengan menggunakan uji kolmogorov smirnov pada taraf signifikansi $\alpha=0,05$. Dari hasil pengujian normalitas data diperoleh bahwa secara keseluruhan dinilai sig. > 0,05, maka dapat disimpulkan seluruh data adalah berdistribusi normal.

\section{Homogenitas Data}

Setelah uji normalitas selesai dan data dinyatakan normal maka selanjutnya dilakukan uji homogenitas. Untuk mengetahui varians data homogen atau tidak dapat diketahui dari nilai signifikannya. Apabila nilai Sig. > 0,05 maka data homogen. Jika uji homogenitas ini terpenuhi maka dilanjutkan dengan pengujian hipotesis.

\section{PEMBAHASAN}

Terdapat perbedaan hasil belajar Fisika siswa dengan model pembelajaran Inquiry Training berbasis Multimedia dan Inquiry Training

Model pembelajaran Inquiry Training berbasis Multimedia dan model pembelajaran Inquiry Trainingpada dasarnya memberikan kesempatan bagi siswa sesuai dengan kemampuan yang dimilikinya untuk memperdalam pemahaman tentang konsep-konsep dasar yang dimiliki, khususnya yang berkaitan dengan materi pokok yang dipelajari siswa, baik melalui guru maupun melalui belajar mandiri. Pembelajaran Inquiry Training adalah salah satu bentuk pembelajaran yang terprogram dan pengajaran yang terprogram merupakan salah satu pengajaran individu yang merujuk pada satu siasat untuk mengatur proses pengajaran sedemikian rupa sehingga setiap siswa memperoleh hasil belajar yang optimal. Hal yang membedakan kedua kelas tersebut adalah media yang digunakan guru yaitu multimedia sedangkan untuk kelas kontrol tidak menggunakan media tersebut.

Hasil temuan dalam penelitian ini membuktikan bahwa rata-rata hitung hasil belajar Fisika kelas Inquiry Training berbasis Multimedia adalah 78,54 lebih tinggi dibandingkan rata-rata hasil belajar Fisika kelas Inquiry Training adalah 75,69 sehingga diper- 
oleh rata-rata nilai gain hasil belajar Fisika kelas Inquiry Training berbasis Multimedia adalah 0,53 lebih tinggi dibandingkan rata-rata nilai gain hasil belajar Fisika kelas Inquiry Training adalah 0,46. Hal ini dapat dipahami bahwa hasil belajar Fisika kelas Inquiry Training berbasis Multimedia lebih tinggi dari pada kelas Inquiry Training.

Selanjutnya dengan model pembelajaran Inquiry Training, siswa yang di ajar siswa akan lebih bebas mengkomunikasikan temuan yang diperolehnya dengan kelompoknya pada saat melakukan kegiatan belajar. Komunikasi antar teman memberikan solusi yang cepat bagi siswa untuk melengkapi ketidaktahuannya tentang materi pokok yang dipelajari. Kemudian ditambah lagi dengan penggunaan multimedia di kelas eksperimen membuat siswa lebih memahami proses pembelajaran.

Terdapat perbedaan hasil belajar Fisika siswa yang memiliki motivasi rendah dengan siswa yang memiliki motivasi belajar tinggi.

Motivasi belajar sangat berpengaruh terhadap hasil belajar Fisika siswa. Dengan demikian siswa yang memiliki motivasi belajar rendah cenderung memperoleh nilai yang kurang memuaskan. Sedangkan siswa yang memiliki motivasi tinggi akan selalu berusaha untuk mencapai prestasi sesuai dengan standar yang ditetapkan. Kondisi teruji secara empiris dengan temuan penelitian yang membuktikan bahwa terdapat perbedaan hasil belajar Fisika siswa yang memiliki motivasi rendah dengan kelompok siswa yang memiliki motivasi tinggi.

Hasil temuan dalam penelitian ini membuktikan bahwa nilai gain hasil belajar Fisika kelompok siswa yang memiliki motivasi belajar rendah sebesar 0,48 lebih rendah dibandingkan nilai gain hasil belajar Fisika kelompok siswa yang memiliki motivasi belajar tinggi sebesar 0,51. Hal ini dapat dipahami bahwa siswa yang memiliki motivasi belajar tinggi akan menghasilkan hasil belajar Fisika yang tinggi. Penelitian ini sejalan dengan penelitian Fianora (2009) yang menemukan bahwa pengaruh media komputer dan metode praktikum serta gabungan keduanya terhadap motivasi belajar sangat signifikan yaitu sebesar 82,00 untuk kelas yang menggunakan media komputer; 78,00 untuk kelas yang menggunakan metode praktikum serta untuk kelas gabungan antara media komputer dan metode praktikum sebesar 85,00.

Interaksi antara model pembelajaran Inquiry Training dan Inquiry Training berbasis Multimedia dengan motivasi belajar siswa untuk meningkatkan hasil belajar Fisika

Dari output ANOVA diperoleh Fhitung untuk interaksi (Kelas*Motivasi) lebih besar dari $F_{\text {tabel }}(7,77>3,98)$. Karena itu hipotesis ketiga dalam penelitian ini diterima yaitu terdapat interaksi antara model pembelajaran Inquiry Training dan Inquiry Training berbasis Multimedia dengan motivasi belajar siswa untuk meningkatkan hasil belajar Fisika. Penelitian ini sejalan dengan penelitian Fianora (2009) diperoleh nilai $F_{\text {hitung }}>F_{\text {tabel }}(5,08>4,02)$, artinya terdapat interaksi antara model pembelajaran Inquiry Training dan Inquiry Training berbasis Multimedia dengan motivasi belajar siswa untuk meningkatkan hasil belajar Fisika.

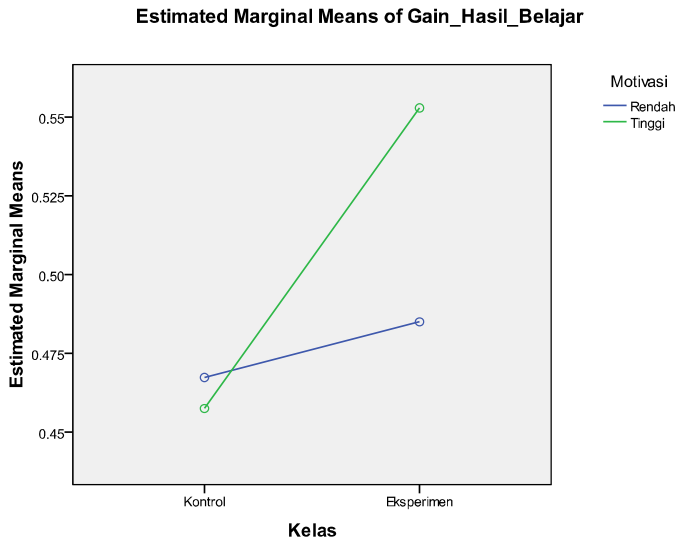

Gambar 1. Grafik Interaksi Antara Model Pembelajaran dengan Motivasi Belajar Siswa

Hipotesis ketiga ini diterima yaitu terdapat interaksi antara model pembelajaran Inquiry Training dan Inquiry Training berbasis Multimedia terhadap motivasi belajar siswa dalam meningkatkan hasil belajar Fisika. 
Artinya model pembelajaran dan motivasi belajar saling mempengaruhi, siswa yang mempunyai motivasi belajar tinggi dengan model pembelajaran akan memperoleh hasil belajar yang tinggi sebaliknya, siswa yang mempunyai motivasi belajar rendah maka hasil belajarnya rendah.

\section{SIMPULAN}

Berdasarkan hasil analisa data dan pembahasan dapat disimpulkan sebagai berikut:

1. Terdapat perbedaan hasil belajar Fisika antara siswa yang menggunakan model pembelajaran Inquiry Training Berbasis Multimedia dibandingkan dengan siswa yang menggunakan model pembelajaran Inquiry Training.

2. Terdapat perbedaan hasil belajar Fisika siswa yang memiliki motivasi belajar tinggi lebih baik dari pada siswa yang memiliki motivasi belajar rendah.

3. Terdapat interaksi antara model pembelajaran dengan motivasi dalam mempengaruhi hasil belajar Fisika siswa.

\section{DAFTAR PUSTAKA}

Fianora, E. 2009. Efektivitas Media Komputer dan Metode Praktikum terhadap Motivasi dan Hasil Belajar Kimia Siswa pada Pengajaran Elektrolisis. Medan: Tesis pascasarjana UNIMED prodi Kimia.
Joyce, B., dan Weil, M. 2009. Models of Teaching. Yogyakarta: Pustaka Pelajar.

Mayer, R. E. 2009. Multimedia Learning. Yogyakarta: Pustaka Pelajar.

Mudjiono. 2009. Pengaruh model pembelajaran inquiry training berbasis portopolio dan penggunaan media komputer terhadap hasil belajar kimia di SMA N se-kota Binjai. Medan: Tesis pascasarjana Unimed prodi Kimia.

Sinaga, S.W. 2011. Pengaruh Strategi Pembelajaran POGIL menggunakan animasi komputer dalam meningkatkan hasil belajar kimia SMA pada Materi Pokok Stokiometri. Medan: Tesis pascasarjana UNIMED prodi Kimia.

Sardiman. 2011. Interaksi dan Motivasi Belajar Mengajar. Jakarta: Penerbit Grafindo.

Sitepu, R. 2012. Penerapan Model Pembelajaran Inquiry Training Untuk Meningkatkan Hasil Belajar Siswa Kelas VII-2 Tiga Panah Pada Pelajaran Bahasa Inggris. Journal Penelitian Peningkatan Kualitas Pembelajaran Dikelas.

Sudjana, N. 2010. Penilaian Hasil proses belajar mengajar. Bandung: Rosda karya.

Trianto. 2007. Mendesain Model-Model Pembelajaran Inovatif Berorientasi Konstruktivistik. Jakarta: Prestasi Pustaka. 